\title{
Pengaruh Supervisi Dan Peran Kepala Sekolah Terhadap Kinerja Mengajar Guru SD Negeri Di Kecamatan Rumbai Pesisir
}

\author{
Teddy Okto Prahara ${ }^{1 *}$, Iqbal Miftakhul Mujtahid ${ }^{2}$, Tita Rosita ${ }^{3}$ \\ ${ }^{1.2 .3}$ Universitas Terbuka, Indonesia \\ ${ }^{1}$ teddyokto79@gmail.com \\ 2iqbal@ecampus.ut.ac.id \\ 3tita@ecampus.ut.ac.id
}

Received: 13 August 2021; Revised: 02 October 2021; Accepted: 24 December 2021

DOI: http://dx.doi.org/10.37905/aksara.8.1.75-86.2022

\begin{abstract}
Abstrak
Penelitian ini bertujuan untuk mengetahui pengaruh supervisi dan peran kepala sekolah terhadap kinerja mengajar guru SD Negeri di kecamatan Rumbai Pesisir Data dalam penelitian ini diperoleh dari kuesioner yang bersumber dari guru. Data dianalisis menggunakan regresi berganda. Hasil penelitian menunjukkan bahwa: 1) Terdapat pengaruh yang signifikan antara supervisi dan Peran kepala sekolah terhadap kinerja mengajar guru SD Negeri di kecamatan Rumbai Pesisir, dimana $F_{\text {hitung }}(61,101)>F_{\text {tabel }}$ $(1,654)$. Berdasarkan koofisien determinasi $=0.441$ atau $44,1 \%$. Besar pengaruh supervisi dan peran kepala sekolah terhadap kinerja mengajar guru SD Negeri di kecamatan Rumbai Pesisir sebesar 44,1\% berada pada tingkat sedang. 2) Terdapat pengaruh yang signifikan antara peran supervisi terhadap kinerja mengajar guru SD Negeri di kecamatan Rumbai Pesisir, dimana $F_{\text {hitung }}(6,173)>F_{\text {tabel }}(1,654)$. Berdasarkan koofisien determinasi $(\mathrm{R}$ Square $)=0.440$ atau $44 \%$. Besar pengaruh supervisi dan peran kepala sekolah terhadap kinerja mengajar guru SD Negeri di kecamatan Rumbai Pesisir sebesar $44 \%$ berada pada tingkat sedang. 3) Terdapat pengaruh yang signifikan antara peran kepala sekolah terhadap kinerja mengajar guru SD Negeri di Kecamatan Rumbai Pesisir, dimana $F_{\text {hitung }}(5,417)>F_{\text {tabel }}(1,654)$. Berdasarkan koofisien determinasi $(\mathrm{R}$ Square $)=0.403$ atau 40,3\%. Besar pengaruh supervisi dan peran kepala sekolah terhadap kinerja mengajar guru SD Negeri di kecamatan Rumbai Pesisir sebesar 40,3\% berada pada tingkat sedang. Kesimpulan dari penelitian ini bahwa supervisi dan peran kepala sekolah berpengaruh positif dan signifikan terhadap kinerja mengajar guru SD Negeri di kecamatan Rumbai Pesisir.
\end{abstract}

Kata Kunci: Kinerja mengajar guru, Supervisi, Peran Kepala Sekolah,

\section{PENDAHULUAN}

Pendidikan memiliki peran yang begitu besar untuk pertumbuhan dan perkembangan suatu bangsa. Berbagai upaya dilakukan untuk memajukan pendidikan agar tercipta kualitas pendidikan yang baik. Oleh sebab itu tidak dapat dipungkiri bahwa pendidikan merupakan inti dari kemajuan suatu bangsa. Hal ini tentunya tidak akan pernah terlepas dari peran serta guru, kepala sekolah beserta pihak-pihak terkait sebagai warga sekolah yang berhubungan langsung dengan sekolah. Rendahnya kualitas pendidikan masih menjadi salah satu problematika di dunia pendidikan di Negara Indonesia, terlihat dari beberapa tahun terakhir ini kualitas dari pendidikan di Negara ini masih memprihatinkan. Berbagai macam usaha dan upaya sudah dilakukan oleh pemerintah, namun kualitas pendidikan di Indonesia masih saja memprihatinkan.

Menurut pemaparan Anies Baswedan dalam (Widodo 2016) yang disampaikannya dalam silaturahmi dengan Kepala Dinas Jakarta pada 1 Desember 2014, Ia mengatakan bahwa Pendidikan di Negara Indonesia berada dalam posisi gawat darurat. Beberapa kasus yang memperlihatkan kondisi tersebut diantaranya adalah rendahnya layanan pendidikan di Indonesia, rendahnya mutu pendidikan di Indonesia, rendahnya mutu 
pendidikan tinggi di Indonesia, dan rendahnya kemampuan literasi anak-anak di Indonesia. Faktor-faktor inilah yang pada akhirnya secara otomatis berdampak secara langsung terhadap para lulusan yang dihasilkan, karena dengan rendahnya kualitas pendididkan maka rendah pula kualitas para lulusan yang dihasilkan. Melihat kondisi rendahnya kualitas pendidikan, tentunya tidak akan bisa terlepas dari faktor-faktor tertentu yang secara langsung ataupun tidak langsung dapat berpengaruh terhadap kualitas pendidikan, seperti terjadinya distorsi pada sumber daya yang terdapat didalamnya yakni kepala sekolah, guru dan siswa yang terlibat aktif. Hal ini diperkuat oleh (Solehan 2014) yang mengatakan bahwa faktor-faktor yang mempengaruhi mutu pendidikan adalah: 1) Sumber daya manusia yang terdiri dari kepala sekolah, guru dan tenaga administrasi, 2) Sarana dan prasarana, 3) Kesiswaan, 4) Keuangan, 5) kurikulum, 6) keorganisasian, 7)Lingkungan fisik, 8) Perkembangan ilmu pengetahuan, 9) Peraturan, 10) Partisipasi atau peran serta masyarakat, 11) Kebijakan pendidikan. Berdasarkan faktor-faktor tersebut, salah satu faktor penting yang dapat meningkatkan kualitas dan mutu pendidikan di suatu sekolah adalah melalui peran kepala sekolah. (Ekosiswoyo 2016) juga mengatakan bahwa kepala sekolah adalah pengelola terdepan yang memutuskan dapat tidaknya setiap input berproses dan bereaksi secara positif dalam sistem belajar mengajar.

Peran seorang kepala sekolah juga bisa menjadi tolak ukur dalam pencapaian kinerja mengajar guru yang baik untuk dapat meningkatkan kualitas sekolah. Kepala sekolah merupakan seorang yang mengatur dan mengelola aktifitas pendidikan yang dilakukan oleh guru supaya lebih terarah, terfokus dan dapat mengalami peningkatan.

Peran kepala sekolah sebagai pimpinan sangat penting dalam meningkatkan kinerja guru untuk lebih semangat dan professional dalam meningkatkan kinerjanya. Hal ini menunjukkan bahwa guru diharapkan mampu berperan aktif sebagai pengelola proses belajar mengajar dibawah bimbingan dan pengawasan kepala sekolah. Seorang guru yang dianggap sudah mampu menjalankan tugasnya sebagai seorang pendidik ternyata masih perlu pengawasan dan bimbingan dari berbagai pihak.

Pentingnya peran kepala sekolah juga didukung oleh (Mulyasa 2012) yang menyebutkan bahwa kepala sekolah merupakan salah satu komponen pendidikan yang paling berperan dalam meningkatkan kualitas pendidikan.

Dalam meningkatkan mutu dan kualitas pendidikan disekolah kepala sekolah harus menjalankan perannya sebagai pimpinan dengan baik dan benar. Salah satunya adalah dengan melaksanakan supervisi terhadap guru. Supervisi merupakan pengawasan, monitoring, dan penilaian atau evaluasi pengajaran yang ditujukkan untuk perbaikan pengajaran. Perbaikan pengajaran itu dilakukan dengan cara peningkatan kemampuan professional guru dalam melaksanakan tugasnya. Gunanya adalah untuk membantu mendorong dan memberi keyakinan kepada guru, bahwa proses belajar mengajar dapat dan harus diperbaiki serta melakukan berbagai pengembangan berbagai pengalaman, pengetahuan, sikap dan keterampilan guru harus dibantu secara professional sehingga guru tersebut dapat berkembang dalam tugasnya.

Menurut (Mulyasa 2012) tujuan supervisi pendidikan diantaranya yaitu:

1) Membina kepala sekolah dan guru untuk lebih memahami tujuan pendidikan yang sebenarnya dan peranan sekolah dalam merealisasikan tujuan tersebut.

2) Memperbesar kesanggupan kepala sekolah dan guru untuk mempersiapkan peserta didiknya menjadi anggota masyarakat yang lebih efektif. 
3) Membantu kepala sekolah dan guru mengadakan diagnosis secara kritis terhadap aktivitasnya dan kesulitan belajar mengajar, serta menolong mereka merencanakan perbaikan.

4) Meningkatkan kesadaran kepala sekolah dan guru serta warga sekolah lain terhadap cara kerja yang demokratis dan komprehensif, serta memperbesar kesediaan untuk tolong menolong.

5) Memperbesar semangat guru dan meningkatkan motivasi berprestasi untuk mengoptimalkan kinerja secara maksimal dalam profesinya.

6) Melindungi orang yang disupervisi terhadap tuntutan yang tidak wajar dan kritik yang tidak sehat dari masyarakat.

7) Membantu kepala sekolah dan guru dalam mengevaluasi aktivitasnya untuk mengembangkan aktivitas dan kreativitas peserta didik.

Supervisi secara umum dapat diartikan sebagai arahan serta pengendalian kepada tingkat karyawan yang berada dibawahnya dalam suatu organisasi atau kelompok. Sedangkan pengertian supervisi dalam bidang pendidikan adalah pembinaan yang berupa tuntunan atau pembinaan kearah perbaikan situasi pendidikan pada umumnya serta peningkatan mutu mengajar, belajar, dan pembelajaraan.

Ara hidayat dan Imam Machali dalam (Sarifudin 2019) juga mengatakan bahwa secara etimologi supervisi berasal dari kata "super" dan "vision", super bisa bermakna kelebihan, orang yang mempunyai kelebihan jika dibandingkan orang lain.

Menurut (Sayiful Mustofa 2013), menyatakan "Supervision is assistance in the development of better teaching learning situation". Supervisi adalah bantuan dalam pengembangan siatuasi pembelajaran yang lebih baik. Situasi belajar yang dimaksud adalah situasi belajar yang memperhatikan tujuan, materi ajar, teknik, metode, guru, siswa dan lingkungan belajar.

Supervisi juga bisa diartikan pembinaan yang diberikan kepada seluruh staff yang berada disekolah agar mereka dapat meningkatkan kemampuan untuk dapat mengembangkan situasi belajar mengajar kearah yang lebih baik.

Menurut Bordman dalam (Supardi 2013) supervisi pendidikan adalah suatu usaha menstimulir, menkoordinir dan membimbing secara kontinu pertumbuhan guru-guru di sekolah baik secara individual maupun secara kolektif, agar lebih mengerti dan lebih efektif dalam mewujudkan seluruh fungsi pembelajaran dengan demikian mereka dapat menstimulir dan membimbing pertumbuhan setiap murid, sehingga dengan demikian mereka mampu dan lebih cakap berpartisipasi dalam masyarakat demokrasi modern.

Sedangkan pengertian supervisi juga disampaikan oleh Good Carter dalam (Setiadi 2013) bahwa supervisi adalah usaha dari petugas-petugas sekolah dalam memimpin guru-guru dalam memperbaiki pengajaran, termasuk menstimulasi, menyeleksi pertumbuhan jabatan dan perkembangan guru-guru serta merevisi tujuantujuan pendidikan, bahan pengajaran dan metode serta evaluasi pengajaran.

Tinggi atau rendahnya mutu pendidikan suatu sekolah juga dipengaruhi oleh kualitas suatu proses pembelajaran yang dilakukan oleh guru, karena guru merupakan pihak yang secara langsung memberikan bimbingan dan pengajaran kepada peserta didik untuk mencapai suatu tujuan pendidikan. Setiap saat guru diharapakan untuk selalu berupaya meningkatkan kualitas dan kinerjanya dalam melaksanakan tugas supaya tercapai tujuan pendidikan yang diinginkan. 
Kinerja guru merupakan kondisi yang menunjukkan kemampuan seorang guru dalam menjalankan tugasnya disekolah serta menggambarkan adanya suatu perbuatan yang ditampilkan guru dalam atau selama melakukan aktivitas pembelajaran. Kinerja yang baik terlihat dari hasil yang diperoleh dari penilaian peserta didik. Kinerja guru dalam melaksanakan pembelajaran adalah kemampuan yang dimiliki dan ditunjukkan oleh guru dalam melaksanakan tugas atau pekerjaannya. Kinerja dapat dikatakan baik dan memuaskan apabila tujuan yang dicapai sesuai dengan standar yang telah ditetapkan. Kinerja guru tidak hanya ditunjukkan oleh hasil kerja, akan tetapi juga ditunjukkan oleh perilaku dalam bekerja.

Kinerja guru dapat diukur dan dilihat berdasarkan spesifikasi atau kriteria kompetensi yang harus dimiliki oleh setiap guru. Oleh karena itu diperlukan standar kinerja untuk mengukur tingkat kinerja para guru. Standar kinerja perlu dirumuskan untuk dijadikan acuan dalam mengadakan penilaian, yaitu membandingkan apa yang dicapai dengan apa yang diharapkan. Standar kinerja dapat dijadikan patokan dalam mengadakan pertanggungjawaban terhadap apa yang telah dilaksanakan.

Penilaian kinerja seorang guru merupakan bagian penting dari seluruh proses kinerja guru yang bersangkutan. (Martinis Yamin 2010) mengatakan bahwa sumber penilaian tenaga kependidikan adalah: 1) penilaian atas diri sendiri, 2) penilaian oleh siswa, 3) penilaian oleh rekan sejawat, 4) penilaian oleh atasan langsung. Sedikitnya ada sepuluh faktor yang dapat meningkatkan kinerja guru antara lain: dorongan untuk bekerja (motivasi kerja), tanggung jawab terhadap tugas, peluang untuk berkembang, perhatian kepala sekolah melalui supervisi, hubungan interpersonal dengan sesama guru, Musyawarah Guru Mata Pelajaran (MGMP) dan Kelompok Kerja Guru (KKG), kelompok diskusi terbimbing, serta layanan perpustakaan.

Menurut (Supardi 2013) kinerja guru adalah kemampuan dan keberhasilan guru dalam melaksanakan tugas-tugas pembelajaran yang ditunjukkan oleh dimensi: 1) kemampuan menyusun perangkat pembelajaran, 2) dimensi kemampuan melaksanakan pembelajaran, 3) kemampuan melaksanakan penilaian hasil belajar, 4) kemampuan melaksanakan program pengayakan, 5) kemampuan melaksanakan program remedial. Hal ini senada dengan Undang-undang Nomor 14 Tahun 2005 Bab I Pasal 1 tentang guru dan dosen, disebutkan bahwa guru adalah pendidik professional dengan tugas utama mendidik, mengajar, membimbing, mengarahkan melatih, menilai, dan mengevaluasi peserta didik pada pendidikan anak usia dini jalur pendidikan formal, pendidikan dasar, dan pendidikan menengah.

Kinerja guru dapat diukur dan dilihat berdasarkan spesifikasi atau kriteria kompetensi yang harus dimiliki oleh setiap guru. Oleh karena itu diperlukan standar kinerja untuk mengukur tingkat kinerja para guru. Standar kinerja perlu dirumuskan untuk dijadikan acuan dalam mengadakan penilaian, yaitu membandingkan apa yang dicapai dengan apa yang diharapkan. Standar kinerja dapat dijadikan patokan dalam mengadakan pertanggungjawaban terhadap apa yang telah dilaksanakan.

Menurut (Suharsaputra 2010) bahwa pada hakikatnya kinerja guru adalah perilaku yang dihasilkan seorang guru dalam melaksanakan tugasnya sebagai pendidik dan pengajar ketika mengajar di depan kelas, sesuai dengan kriteria tertentu. 
AKSARA: Jurnal Ilmu Pendidikan Nonformal

P-ISSN 2407-8018 E-ISSN 2721-7310 DOI prefix 10.37905

Volume 08, (1), January 2022

http://ejurnal.pps.ung.ac.id/index.php/Aksara

\section{METODE PENELITIAN}

Pendekatan penelitian yang dilakukan menggunakan pendekatan kuantitatif dengan menggunakan metode survey. Pendekatan kuantitatif ini dilakukan untuk mengetahui seberapa besar pengaruh variabel independen (variabel bebas) yang terdiri dari Supervisi (X1), dan Peran Kepala Sekolah (X2) terhadap variabel dependen (variabel terikat) yaitu Kinerja Guru (Y). Analisis hasil dan pembahasan penelitian ini menggunakan penelitian kausal-asosiatif yang menyatakan hubungan sebab akibat antara variabel independen (variabel yang mempengaruhi) dengan variabel dependen (variabel yang dipengaruhi).

Dalam penelitian pengaruh supervisi dan peran kepala sekolah terhadap kinerja guru, yang dijadikan populasi adalah guru-guru yang bertugas di SD Negeri yang ada di Kecamatan Rumbai Pesisir yang berjumlah 262 orang. Populasi pada penelitian ini diambil dari Sekolah Dasar-Sekolah Dasar Negeri yang ada di Kecamatan Rumbai Pesisir yang jumlah gurunya berbeda-beda dalam setiap sekolah. Terkait dengan hal itu, maka teknik pengambilan sampel yang digunakan dalam penelitian ini adalah propotional random sampling. Teknik ini digunakan karena populasi mempunyai anggota yang heterogen, dalam hal ini berbeda jumlah anggota dari masing-masing sekolah.

Sampel adalah sebahagian anggota populasi yang memberi keterangan atau data yang diperlukan dalam suatu penelitian. Sampel sendiri secara harfiah artinya adalah contoh. Sampel yang baik adalah yang bisa mempresentasikan populasi penelitian. Oleh karena itu jumlah sampel yang diagunakan harus diestimasi dengan tepat.(Sugiyono 2016)

Estimasi besaran sampel pada penelitian ini ditentukan berdasarkan rumus Slovin dalam (Sugiyono 2016) taraf signifikan 5\%. Jadi sampel yang diambil dalam penelitian ini berjumlah 158 orang guru.

Instrumen yang yang digunakan dalam penelitian ini adalah menggunakan kuesioner. Kuesioner yang digunakan dalam penelitian ini digunakan untuk menjaring data tentang supervisi, peran kepala sekolah dan kinerja guru. Skala pengukuran instumen yang digunakan dalam penelitian ini adalah skala likert untuk semua variabel.

Instrumen yang digunakan dalam penelitian ini merupakan instrumen yang dibuat sendiri oleh peneliti melalui tahapan-tahapan yakni: Pertama, pengkajian teori yang berkaitan dengan variabel yang diteliti sehingga dapat ditentukan konstruk dari variabel tersebut. Kedua, penentuan indikator dari masing-masing variabel. Ketiga, penyusunan kisi-kisi instrument. Keempat, penyusunan butir pernyataan, dan penetapan skala pengukurannya. Kelima, pelaksanaan uji coba instrument dan setelah itu dilakukan uji validitas dan perhitungan reliabilitas dari masing-masing butir pernyataan.

Dengan penggunaan skala likert maka variabel yang akan diukur diuraikan menjadi indikator-indikator variabel. Kemudian faktor-faktor tersebut dijadikan dasar untuk menyusun item-item instrumen yang dapat berupa pernyataan.

Pada penelitian ini, uji normalitas data menggunakan uji Kolmogorov-smirnov, dengan taraf signifikan yang digunakan sebagai aturan untuk menerima atau menolak pengujian normalitas atau ada tidaknya suatu distribusi data $\alpha=0,05$. Untuk menerima atau menolak hipotesis dengan cara membandingkan nilai signifikan variable dengan $\alpha$ $=0,05$. Data dinyatakan berdistribusi normal jika nilai signifikan $>\alpha=0,05$. 
Pengujian linieritas antar variabel penelitian diolah dengan menggunakan SPSS versi 22. Kaidah keputusan untuk menentukan linier atau tidaknya suatu bentuk hubungan regresi adalah dengan membandingkan nilai signifikansi pada baris linearity dengan nilai $\alpha=0,05$. Jika nilai signifikansi pada baris linierity $<0,05$, maka hubungannya linier.

\section{HASIL DAN PEMBAHASAN}

Data dalam penelitian ini meliputi tiga (3) variabel, yaitu variabel supervisi (X1), variabel peran kepala sekolah (X2), dan variabel kinerja guru (Y). Secara singkatnya dapat dikatakan bahwa deskripsi data ini nantinya akan menggambarkan informasi tentang rata-rata (mean), nilai tengah (median), angka yang sering muncul (modus), simpangan baku (standar deviasi), keragaman (variansi), rentang data (range), nilai terendah (minimum), dan nilai tertinggi (maximum).

Data kinerja guru (Y) diperoleh skor rata-rata kinerja guru di SD Negeri Kecamatan Rumbai Pesisir sebesar 147, 17. Nilai varian sebesar 104,71 yang berarti nilai rata-rata lebih tinggi dari pada nilai varian, yang artinya kinerja guru disetiap sekolah dasar di Kecamatan Rumbai Pesisir memiliki kinerja guru yang hampir sama. Sebaran nilai sampel kinerja guru sekolah dasar negeri di Kecamatan Rumbai Pesisir (Std Deviasi) sebesar 10,233 yang menunjukkan besar perbedaandari nilai sampel kinerja guru di sekolah dasar negeri di kecamatan Rumbai Pesisir terhadap rata-rata cukup tinggi, varians yang rendah sebesar 104,71 menunjukkan nilai kinerja guru di sekolah dasar negeri di kecamatan Rumbai Pesisir hampir sama. Skor terendah kinerja guru sekolah dasar negeri di Kecamatan Rumbai Pesisir sebesar 125, yang artinya dibawah dari nilai rata-rata, dan skor tertinggi sebesar 165 yang menunjukkan data kinerja guru sekolah dasar negeri di kecamatan Rumbai Pesisir sedang. Dengan rentang skor data kinerja guru yang diperoleh dari skor tertinggi dan skor terendah terdapat perbedaan yang signifikan, yang berarti kinerja guru sekolah dasar negeri di kecamatan Rumbai Pesisir ada yang rendah dan ada yang tinggi. Jumlah data kinerja guru setelah dijumlahkan sebesar 23.253.

Data supervisi diperoleh skor rata-rata supervisi (X1) sebesar 136,34. Nilai varian 138,58. Nilai varian lebih tinggi dari nilai rata-rata yang berarti pelaksanaan supervisi pada setiap SD Negeri di Kecamatan Rumbai Pesisir beragam. Sebaran nilainilai sampel supervisi SD Negeri di Kecamatan Rumbai Pesisir (Std. Deviasi) sebesar 11,772 yang menunjukkan besarnya perbedaan dari nilai sampel supervisi SD Negeri di Kecamatan Rumbai Pesisir terhadap rata-rata. Nilai varian yang tinggi menunjukkan nilai supervisi yang beragam. Skor terendah supervisi SD Negeri di Kecamatan Rumbai Pesisir sebesar 106 yang berarti termasuk kedalam kategori baik, dan skor tertinggi supervisi SD Negeri di Kecamatan Rumbai Pesisir sebesar 155 yang termasuk dalam kategori sangat baik. Dengan rentang skor yang diambil dari selisih skor terendah dan tertinggi, maka terlihat perbedaan yang tidak begitu signifikan, yang artinya pelaksanaan supervisi di SD Negeri di Kecamatan Rumbai Pesisir ada yang baik dan ada yang sangat baik.

Data peran kepala sekolah diperoleh skor rata-rata sebesar 131,70. Nilai varian 92,554. Nilai varian lebih rendah dari nilai rata-rata yang berarti peran kepala sekolah di SD Negeri di Kecamatan Rumbai Pesisir hamper sama. Sebaran nilai-nilai sampel supervisi SD Negeri di Kecamatan Rumbai Pesisir (Std. Deviasi) sebesar 9,620 yang 
menunjukkan besarnya perbedaan dari nilai sampel peran kepala sekolah di SD Negeri di Kecamatan Rumbai Pesisir terhadap rata-rata. Nilai varian yang rendah menunjukkan nilai peran kepala sekolah yang hampir sama. Skor terendah peran kepala sekolah di SD Negeri di Kecamatan Rumbai Pesisir sebesar 117 yang berarti termasuk kedalam kategori baik, dan skor tertinggi peran kepala sekolah di SD Negeri di Kecamatan Rumbai Pesisir sebesar 150 yang termasuk dalam kategori sangat baik. Dengan rentang skor yang diambil dari selisih skor terendah dan tertinggi, maka terlihat perbedaan yang tidak begitu signifikan, yang artinya peran kepala sekolah di SD Negeri di Kecematan Rumbai Pesisir ada yang baik dan ada yang sangat baik.

Hipotesis penelitian adalah untuk mengetahui pengaruh signifikan supervisi dan peran kepala sekolah terhadap kinerja mengajar guru.

\section{Hipotesis Pertama}

Hipotesis yang dikemukakan, apakah terdapat pengaruh signifikan supervisi (X1) dan peran kepala sekolah (X2) terhadap kinerja mengajar guru. Untuk mengetahui pengaruh X1 dan X2 terhadap Y, dapat dilihat pada tabel berikut ini :

Tabel 1 Hasil Uji F Model Regresidva=

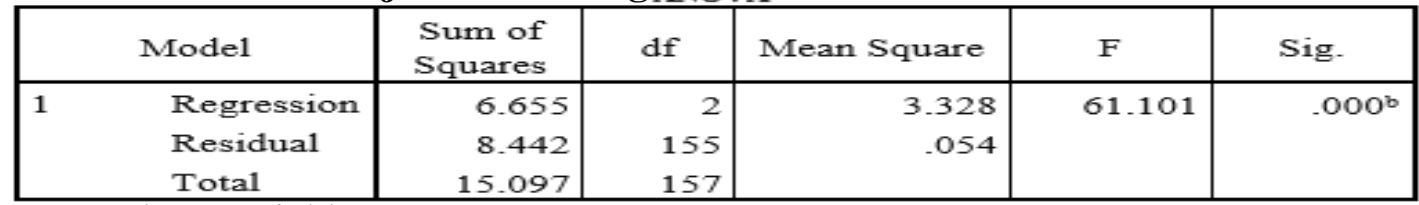

a. Dependent Variable: Y

b. Predictors: (Constant), X2, X1

Berdasarkan hasil dari $F_{\text {hitung }}=61,101>F_{\text {tabel }}=1,654$, dengan taraf signifikan 0,05 , maka $\mathrm{H}_{0}$ ditolak, yang menjelaskan bahwa terdapat pengaruh signifikan antara $\mathrm{X} 1$ dan X2 secara bersamaan terhadap Y.

Besarnya peran supervisi dan peran kepala sekolah terhadap kinerja guru dapat dilihat pada tabel berikut ini:

Tabel 2 Hasil Uji F Model Regresi

\begin{tabular}{|l|r|r|r|r|}
\hline Model & Model Summaryb & \multicolumn{1}{c|}{$\begin{array}{c}\text { Std. Error of the } \\
\text { Estimate }\end{array}$} \\
\hline 1 & $.664^{\mathrm{a}}$ & $\mathrm{R}$ Square & Adjusted R Square & \begin{tabular}{c} 
Adimat \\
\hline
\end{tabular} \\
\hline
\end{tabular}

Dari hasil perhitungan koofisien determinasi ( $\mathrm{R}$ Square ) $=0,441$ atau 44,1\%. Ini berarti pengaruh variabel supervisi dan peran kepala sekolah terhadap kinerja guru secara bersamaan sebesar $44,1 \%$.

Berkenaan dengan persamaan regresi linier berganda, dapat terlihat pada tabel berikut ini: 
Tabel 3. Koofisien Regresi Berganda

\begin{tabular}{|c|c|c|c|c|c|c|}
\hline \multicolumn{7}{|c|}{ Coefficients ${ }^{a}$} \\
\hline & \multirow[t]{2}{*}{ Model } & \multicolumn{2}{|c|}{$\begin{array}{c}\text { Unstandardized } \\
\text { Coefficients }\end{array}$} & \multirow{2}{*}{$\begin{array}{c}\text { Standardized } \\
\text { Coefficients }\end{array}$} & \multirow[t]{2}{*}{$\mathrm{t}$} & \multirow[t]{2}{*}{ Sig. } \\
\hline & & $\mathrm{B}$ & Std. Error & & & \\
\hline \multirow[t]{3}{*}{1} & (Constant) & 2.020 & .256 & & 7.884 & .000 \\
\hline & $\mathrm{X} 1$ & .514 & .083 & .629 & 6.173 & .000 \\
\hline & $\mathrm{x} 2$ & .411 & .099 & .425 & 5.417 & .007 \\
\hline
\end{tabular}

Berdasarkan tabel 3. diatas, diperoleh nilai $\mathrm{a}=2,020$, koofisien $\mathrm{b} 1=0,514$, dan koofisien $\mathrm{b} 2=0,411$. Dengan demikian persamaan regresi berganda variabel kinerja guru (Y) atas variabel supervisi (X1) dan peran Kepala sekolah (X2) adalah Y = 2,020 + $0,514 \mathrm{X}_{1}+0,411 \mathrm{X}_{2}$. Dari persamaan regresi tersebut menunjukkan bahwa variabel supervisi dan peran kepala sekolah sudah memiliki pengaruh positif terhadap kinerja guru.

\section{Hipotesis Kedua}

Hipotesis yang diajukan adalah apakah terdapat pengaruh signifikan supervisi (X1) terhadap kinerja mengajar guru (Y). Dari tabel 3 diatas dapat dilihat $t_{\text {hitung }}=6,173$, diketahui $\mathrm{n}=158$, maka df $=\mathrm{n}-\mathrm{k}=158-2=156$. Dibandingkan dengan $\mathrm{t}_{\text {tabel }}$ pada $\mathrm{df}=$ 156 dengan taraf signifikan 0,05 maka didapat nilai $t_{\text {tabel }}=1,654$. Kemudian dilakukan perbandingan antara $t_{\text {hitung }}$ dengan $t_{\text {tabel, }}$ maka didapat $t_{\text {hitung }}(6,173)>t_{\text {tabel }}(1,654)$. Dengan demikian $t_{\text {hitung }}>t_{\text {tabel}}$, maka $\mathrm{H}_{0}$ ditolak dan $\mathrm{H}_{\mathrm{a}}$ diterima. Artinya variabel supervisi berpengaruh secara signifikan terhadap kinerja guru di SD Negeri di Kecamatan Rumbai Pesisir. berikut ini:

Besarnya pengaruh supervisi terhadap kinerja guru dapat dilihat pada tabel

\section{Tabel 4. Koofisien Determinasi}

\begin{tabular}{|c|r|r|r|r|}
\hline Model & $\mathrm{R}$ & $\mathrm{R}$ Square & $\begin{array}{c}\text { Adjusted } \mathrm{R} \\
\text { Square }\end{array}$ & $\begin{array}{c}\text { Std. Error of the } \\
\text { Estimate }\end{array}$ \\
\hline 1 & $.663^{\mathrm{a}}$ & .440 & .437 & .23275 \\
\hline
\end{tabular}

Dari tabel 4. diatas dapat diketahui bahwa hasil perhitungan koofisien determinasi $(\mathrm{R}$ square) $=0,440$ atau $44 \%$. Ini berarti pengaruh variabel supervisi terhadap kinerja guru sebesar $44 \%$.

\section{Hipotesis Ketiga}

Hipotesis yang diajukan adalah apakah terdapat pengaruh signifikan peran kepala sekolah terhadap kinerja guru. Dari tabel 4.12 dapat dilihat $\mathrm{t}_{\text {hitung }}=5,417$. Diketahui $\mathrm{n}=$ 158 , maka df $=\mathrm{n}-\mathrm{k}=158-2=156$. Dilakukan perbandingan dengan $\mathrm{t}$ tabel pada $\mathrm{df}=$ 156 dengan taraf signifika 0,05 , maka didapat nilai $\mathrm{t}_{\text {tabel }}=1,654$. Maka hasilnya $\mathrm{t}_{\text {hitung }}$ $(5,417)>t_{\text {tabel }}(1,654)$. Dengan demikian karena $\mathrm{t}_{\text {hitung }}>\mathrm{t}_{\text {tabel}}$, maka $\mathrm{H}_{0}$ ditolak dan $\mathrm{H}_{\mathrm{a}}$ diterima. Artinya terdapat pengaruh signifikan peran kepala sekolah terhadap kinerja guru. Besarnya pengaruh peran kepala sekolah terhadap kinerja guru dapat dilihat pada tabel berikut ini: 
AKSARA: Jurnal Ilmu Pendidikan Nonformal

P-ISSN 2407-8018 E-ISSN 2721-7310 DOI prefix 10.37905

Volume 08, (1), January 2022

http://ejurnal.pps.ung.ac.id/index.php/Aksara

Tabel 5 Koofisien Determinasi

Model Summaryb

\begin{tabular}{|l|r|r|r|r|}
\hline Model & $\mathrm{R}$ & $\mathrm{R}$ Square & \multicolumn{1}{|c|}{$\begin{array}{c}\text { Adjusted } \mathrm{R} \\
\text { Square }\end{array}$} & $\begin{array}{c}\text { Std. Error of the } \\
\text { Estimate }\end{array}$ \\
\hline 1 & $.551^{\mathrm{a}}$ & .403 & .399 & .25965 \\
\hline
\end{tabular}

Dari hasil perhitungan koofisien determinasi ( $\mathrm{R}$ Square ) $=0,403$ atau 40,3\% . Ini berarti pengaruh variabel peran kepala sekolah terhadap kinerja guru SD Negeri di Kecamatan Rumbai pesisir sebesar 40,3\%.

\section{PEMBAHASAN}

\section{Pengaruh Supervisi (X1) dan Peran Kepala Sekolah (X2) terhadap Kinerja Mengajar Guru (Y)}

Hasil penelitian menyatakan bahwa supervisi dan peran kepala sekolah berpengaruh positif dan signifikan terhadap kinerja mengajar guru. Supervisi dan peran kepala sekolah harus dilaksanakan sejalan sehingga dapat meningkatkan kinerja mengajar guru. Hasil penelitian ini sejalan dengan penelitian yang dilakukan oleh (Aprida, Fitria, and Nurkhalis 2020) yang berjudul "Pengaruh Supervisi Kepala Sekolah dan Motivasi Kerja Terhadap Kinerja Guru." Penelitian ini menyimpulkan bahwa supervisi kepala sekolah berpengaruh positif dan signifikan terhadap kinerja guru disekolah. Penelitian yang sejalan juga dilakukan oleh (Lastriyani and Herawan 2013) yang berjudul Pengaruh Supervisi Kepala Sekolah dan Kompensasi Terhadap Kinerja Mengajar Guru. penelitian ini dikemukakan bahwa kondisi kinerja mengajar guru dikategorikan "baik", yang artinya kinerja mengajar guru untuk indikator perencanaan pembelajaran, pelaksanaan pembelajaran, serta tindak lanjut hasil pembelajaran telah dilaksanakan dengan baik dilingkungan SD baik negeri maupus swasta di Kota Sukabumi. Terdapat pengaruh yang positif dan signifikan dari supervisi akademik kepala sekolah terhadap kinerja mengajar guru di SD Negeri dan Swasta di kota Sukabumi.

Berdasarkan penelitian terdahulu dan teori para ahli dapat disimpulkan bahwa supervisi dan peran kepala sekolah sangat berpengaruh dalam meningkatkan kinerja mengajar guru. Ketika supervisi dilaksanakan dengan baik maka kinerja mengajar guru akan meningkat, tetapi sebaliknya jika supervisi tidak dilaksanakan dengan baik, maka kinerja mengajar guru juga akan menurun. Begitu juga halnya peran kepala sekolah. Kepala sekolah sangat berperan penting dalam meningkatkan kinerja mengajar guru disekolah. Jika kepala sekolah menjalankan perannya dengan baik, maka kinerja mengajar guru akan meningkat, begitu juga sebaliknya, jika kepala sekolah tidak menjalankan perannya dengan baik, maka kinerja mengajar guru dapat menunjukkan penurunan.

\section{Pengaruh Supervisi (X1) terhadap Kinerja Mengajar Guru (Y)}

Dilihat dari hasil penelitian menunjukkan terdapat pengaruh yang positif dan signifikan supervisi terhadap kinerja mengajar guru. Hal ini berarti bahwa supervisi yang dilaksanakan secara rutin dan terjadwal akan dapat meningkatkan kinerja mengajar guru. Sebaliknya jika supervisi tidak dilaksanakan secara rutin dan terjadwal, maka kinerja mengajar guru akan bisa menurun dikarenakan tidak adanya penilaian atau 
pengawasan dari pihak yang berwenang. Supervisi bukan hanya melihat bagaimana guru membuat perencanaan pembelajaran, melaksanakan proses pembelajaran, dan menilai hasil pembelajaran. Tetapi, lebih luas lagi. Melalui kegiatan supervisi harus dapat menciptakan suasana yang kondusif di sekolah, sehingga para guru akan merasa mendapatkan motivasi dan semangat untuk meningkatkan kinerjanya. Pemahaman supervisi telah berubah dan bergeser kearah yang lebih luas, kearah menciptakan kondisi-kondisi esensial di sekolah agar terciptanya budaya sekolah yang merangsang terjadinya semangat mengajar yang bermutu (Suhardan 2010). Hasil temuan yang serupa juga ditemukan dalam penelitian terdahulu yang dilakukan oleh (Rismawan 2015) dengan judul penelitian "Pengaruh Supervisi Kepala Sekolah dan Motivasi Berprestasi Guru Terhadap Kinerja Kinerja Mengajar Guru”. Dalam penelitian ini dapat diperoleh hasil antara lain gambaran supervisi kepala Sekolah Dasar Negeri di wilayah Dinas Pendidikan dan Kebudayaan Kecamatan Kerta Sari Kabupaten Bandung berada pada kategori baik. Berdasarkan hasil analisis model struktural diperoleh kesimpulan bahwa supervisi kepala sekolah berpengaruh terhadap motivasi berprestasi guru. Kemudian supervisi kepala sekolah juga berpengaruh terhadap kinerja guru. Supervisi merupakan suatu aktifitas pembinaan yang direncanakan untuk membantu para guru dan pegawai sekolah lainnya dalam melakukan pekerjaan secara efektif. Supervisi diartikan sebagai bantuan yang berupa dorongan, bimbingan, dan kesempatan bagi pertumbuhan keahlian dan kecakapan guru-guru yang diberikan oleh pimpinan sekolah (Purwanto 2014). Sedangkan (Supardi 2013) mengatakan bahwa supervisi adalah suatu usaha menstimulir, mengkoordinir, dan membimbiong secara kontinue pertumbuhan guruguru disekolah baik secara individual maupun secara kolektif agar lebih mengerti dan lebih efektif dalam mewujudkan seluruh fungsi pembelajaran.

Dari penelitian terdahulu dan teori-teori oleh para ahli diatas dapat disimpulkan bahwa supervisi merupakan suatu kegiatan yang dilaksanakan untuk membantu guruguru dalam mengembangkan pembelajaran kearah yang lebih baik sehingga dapat membantu guru-guru dalam memperbaiki dan meningkatkan kualitasnya sebagai guru yang profesional. Untuk sekolah juga sangat besar dampaknya, dimana sekolah-sekolah yang mempunyai guru-guru yang berkualitas dan profesioanl akan dapat meningkatkan kualitas dari sekolah itu sendiri. Pengaruh positif bukan hanya untuk guru dan sekolahnya saja, tetapi juga akan berdampak langsung terhadap peserta didik. Guru berkualitas dan profesional akan menciptakan peserta didik yang berkualitas juga.

\section{Pengaruh Peran Kepala Sekolah (X2) terhadap Kinerja Mengajar Guru (Y)}

Kepala sekolah dapat diartikan sebagai seorang tenaga fungsional guru yang diberikan tugas untuk memimpin suatu sekolah dimana diselenggarakannya proses belajar mengajar, atau suatu tempat dimana terjadinya interaksi antara guru yang memberikan pelajaran dengan murid yang menerima pelajaran. Artinya kepala sekolah adalah seorang yang mempunyai tugas untuk memimpin dan bertanggung jawab dalam suatu lembaga pendidikan disekolah (Wahjosumidjo 2010).

Hasil penelitian menunjukkan bahwa peran kepala sekolah berpengaruh positif dan signifikan terhadap kinerja mengajar guru. Hal ini menjelaskan bahwa jika kepala sekolah menjalankan perannya sebagai kepala sekolah dengan baik, maka akan dapat meningkatkan kinerja mengajar guru. Sebaliknya jika kepala sekolah tidak berperan dengan baik dalam menjalankan tugasnya sebagai kepala sekolah, maka akan 
menurunkan kinerja mengajar guru. Hasil penelitian ini sejalan dengan hasil penelitian terdahulu yang dilakukan oleh (Fitrah 2017) yaitu tentang peran kepala sekolah dalam meningkatkan mutu pendidikan. Penelitian ini menunjukkan bahwa peran kepala sekolah tidak hanya sebagai pimpinan yang hanya menandatangani surat-surat ataupun sebagai pemimpin dalam upacara, tetapi kepala sekolah punya peran penting dalam meningkatkan kualitas pendidikan melalui monitoring dan evaluasi berkelanjutan, menyususn rencana yang berorientasi pada visi dan misi serta melakukan komunikasi dengan guru,siswa, orang tua murid serta masyarakat sekitar yang berada dilingkungan sekolah. Kepala sekolah dapat diartikan sebagai seorang tenaga fungsional guru yang diberikan tugas untuk memimpin suatu sekolah dimana diselenggarakannya proses belajar mengajar, atau suatu tempat dimana terjadinya interaksi antara guru yang memberikan pelajaran dengan murid yang menerima pelajaran. Artinya kepala sekolah adalah seorang yang mempunyai tugas untuk memimpin dan bertanggung jawab dalam suatu lembaga pendidikan disekolah (Wahjosumidjo 2010).

Berdasarkan penelitian terdahulu dan teori dari para ahli dapat disimpulkan bahwa peran kepala sekolah sangat penting dalam suatu lembaga pendidikan. Peran kepala sekolah sebagai pemimpin pendidikan harus bisa menciptakan situasi belajar mengajar dengan baik sehingga guru-guru dapat mengajar dengan baik. Selain itu kepala sekolah juga berperan dalam meningkatkan profesionalisme guru sehingga guru memiliki kemampuan dalam melaksanakan tugasnya secara baik sesuai dengan tujuan yang diinginkan.

\section{KESIMPULAN}

Supervisi berpengaruh terhadap kinerja mengajar guru SD Negeri di Kecamatan Rumbai Pesisir. Supervisi yang dilakukan secara teratur dan terjadwal akan berpengaruh positif terhadap kinerja mengajar guru. Supervisi merupakan salah satu aspek penting yang dapat meningkatkan kinerja mengajar guru, dimana supervisi merupakan usaha untuk mengembangkan proses pembelajaran kearah yang lebih baik dengan pemberian bantuan dan layanan bagi guru-guru secara perorangan ataupun secara kelompok. Supervisi merupakan upaya dalam rangka meningkatkan profesionalisme guru dalam melaksanakan pembelajaran.

Peran Kepala Sekolah berpengaruh terhadap kinerja mengajar guru SD Negeri di Kecamatan Rumbai Pesisir. Semakin baik kinerja dan peran kepala sekolah maka akan semakin berpengaruh positif terhadap kinerja mengajar guru. Peran kepala sekolah dalam meningkatkan kinerja mengajar guru adalah salah satu unsur pendidikan yang sangat berpengaruh. Penyelenggaraan kegiatan pendidikan, administrasi sekolah, pembinaan tenaga lainnya, merupakan tanggung jawab kepala sekolah. Banyak hal yang dapat dilakukan oleh seorang kepala sekolah untuk meningkatkan kinerja mengajar guru, terutama kepala sekolah harus selalu komitmen dalam menjalankan perannya sebagai Educator, Manager, Administrator, Innovator, Motivator, Supervisor, dan Leader.

Supervisi dan peran kepala sekolah berpengaruh terhadap kinerja mengajar guru SD Negeri di Kecamatan Rumbai Pesisir. Supervisi yang dilaksanakan secara teratur dan terjadwal akan berpengaruh positif terhadap kinerja mengajar guru, dan semakin baik peran kepala sekolah maka akan semakin baik pula kinerja mengajar guru. 


\section{DAFTAR PUSTAKA}

Aprida, Yopi, Happy Fitria, and Nurkhalis. 2020. "Pengaruh Supervisi Kepala Sekolah Dan Motivasi Kerja Guru Terhadap Kinerja Guru." Journal of Education Research 1 (2): 160-64.

Ekosiswoyo, Rasdi. 2016. "Kepemimpinan Kepala Sekolah Yang Efektif Kunci Pencapaian Kualitas Pendidikan.” Jurnal Ilmu Pendidikan 14 (2): 76-82. http://journal.um.ac.id/index.php/jip/article/view/24/322.

Fitrah, Muh. 2017. "Peran Kepala Sekolah Dalam Meningkatkan Mutu Pendidikan." Jurnal Penjaminan Mutu 3 (1): 31. https://doi.org/10.25078/jpm.v3i1.90.

Lastriyani, Indri, and Endang Herawan. 2013. "Pengaruh Supervisi Kepala Sekolah Dan Kompensasi Terhadap Kinerja Mengajar Guru." Jurnal Adminisistrasi Pendidikan Vol.XVII Vol.XVII N (1): 96-106.

Martinis Yamin, Maisah. 2010. Standarisasi Kinerja Guru. Jakarta: GP Press.

Mulyasa, E. 2012. Manajemen Dan Kepemimpinan Kepala Sekolah. Bandung: Rosdakarya.

Purwanto, Ngalim. 2014. Administrasi Dan Supervisi Pendidikan. Bandung: Remaja Rosdakarya.

Rismawan, Edi. 2015. "Pengaruh Supervisi Kepala Sekolah Dan Motivasi Berprestasi Guru Terhadap Kinerja Mengajar Guru," no. 1: 114-32.

Sarifudin. 2019. "Implementasi Supervisi Kepala Sekolah Terhadap Kinerja Guru Dalam Upaya Meningkatkan Kualitas Pembelajaran Di Madrasah Ibtidaiyah Negeri (Min) Kota Bogor" 02 (01).

Sayiful Mustofa, Jasmani Asf. 2013. Supervisi Pendidikan. Yogyakarta: Ar-Ruzz Media.

Setiadi, T. 2013. Pengaruh Kepala Sekolah Sebagai Pendidik, Manager, Motivator, Dan Supervisor Terhadap Kinerja Guru Di SMK Piri 1 Yogyakarta. Yogyakarta: Program Studi Pendidikan Teknik Elektronika, UNY.

Solehan. 2014. "Strategi Peningkatan Mutu Pendidikan Di Madrasah Alliyah Negeri Muara Enim," 1-15

Sugiyono. 2016. Statistika Untuk Penelitian. Bandung: Alfabeta.

Suhardan, D. 2010. Supervisi Profesional. Bandung: Alfabeta.

Suharsaputra. 2010. Administrasi Pendidikan. Bandung: Pt. Refika Aditama.

Supardi. 2013. Kinerja Guru. Jakarta: Pt. Raja Grafindo Persada.

Wahjosumidjo. 2010. Kepemimpinan Sekolah. Jakarta: Raja Grafindo Persada.

Widodo, Heri. 2016. "Potret Pendidikan Di Indonesia Dan Kesiapannya Dalam Menghadapi Masyarakat Ekonomi Asia (Mea)." Cendekia: Journal of Education and Society 13 (2): 293. https://doi.org/10.21154/cendekia.v13i2.250. 